\title{
Preventive examinations participation and satisfaction of women in peri- and postmenopausal age
}

\begin{abstract}
Introduction. Breast cancer is the second major cause of death in the world, after lung cancer. The purpose of screening tests is to diagnose cancer at non-clinical symptoms stage, when the prognosis is good and treatment less costly. Among different currently available screening methods, mammography plays a key role in early breast cancer detection.

Aim. The purpose of this work was to evaluate women's in pre- and postmenopausal age in Lublin basic knowledge about preventive examination, their participation level and satisfaction with mammography.

Material and methods. The study included 258 women, participants of mammography examination at the Witold Chodzko Institute of Rural Health in Lublin and in Specialist Clinic of the Stefan Cardinal Wyszynski Province Specialist Hospital in Lublin, at the turn of years 2011/2012.

The research method was a diagnostic survey and research tool - the Original Questionnaire.

Results. An opinion that prophylaxis should come as a result of aware lifestyle is not common (22.1\% of participants is committed to expand their knowledge about health threats). Almost $20 \%$ of women has never participated in any prevention examination. Approximately $39 \%$ of respondents admitted that they have received an invitation for free examination in mammography mobile unit (MMU). Almost 52\% respondents (out of those who correctly identified the term MMU) said that they are interested in visiting MMUs in the future.

Conclusions. The number of participants taking part in preventive examinations and in screening tests is unsatisfactory. Numerous subjective factors cause this situation. Many women still does not trust mammography tests made in mobile mammography facilities.
\end{abstract}

Keywords: women, breast cancer, screenings, mammography, attitudes.

DOI: $10.1515 /$ pjph-2017-0003

\section{INTRODUCTION}

Preventive examinations are described in National Health Service as one of its tasks. Their spectrum depends on epidemiological circumstances and wealth of the society. These examinations come as a conclusion from saying: "prevention is better than cure" and this reflects a current WHO settlement of putting a special pressure on prevention actions, including screening tests.

Preventive examination is a diagnose based on regular control checks to detect and treat illnesses as soon as possible. Screening controls are proceeded on the whole population or only on people from high-risk groups.

Screening tests are related to secondary prophylaxis. Their purpose is to identify factors, which may suggest presence of affection characterized as inborn defects or civilization affections (so called $21^{\text {st }}$ century diseases), presence of which depends on society development. Screening tests in Poland cover cystic fibrosis, phenylketonuria, congenital hypothyroidism, hearing organ condition among infants and the following among adults: breast cancer, cervical carcinoma, colon cancer, tobacco-related disease. Mammography examination plays a special role in free screening tests in Poland. They are to support an early cancer diagnose with high number of illness in developed countries.

Breast cancer is the second cause of death in the world, after lung cancer. Breast cancer constitutes $11.9 \%$ of all cancer cases. It occurs both in developed and developing countries. In 2008, in EU member states over 330000 breast cancers were detected among women. 89000 died in the next five years after being diagnosed [1].

It is the most commonly diagnosed cancer among women in Poland and the second cause of deaths $[2,3]$.

Statistically, the number of diagnosed cancer is increasing, whereas the number of deaths is decreasing [1]. Therefore, the overall number of women with cancer consequences is growing [3].

Breast cancer, regardless of prognosis and treatment (periodical or permanent) causes a drop in life quality (psychological problems, impaired mobility, lymphedema, complications due to chemotherapy, absences at work or annuity leading to a decrease in income levels) [4-7].

\footnotetext{
${ }^{1}$ Department of Pediatric Endocrinology and Diabetology, Medical University of Lublin, Poland

${ }^{2}$ Chair and Department of Public Health, Medical University of Lublin, Poland
} 
Breast cancer prevention is not only behavioral prophylaxis, but also the pressure put on early diagnose and treatment, which should find a reflection on disease recognition in an early stages of development and on the use of treatment providing the opportunity for less consequences and mutilating surgeries.

In Polish conditions prophylactic actions (by non- governmental organizations, schools and media) are mostly to convince women to breast self-examination $[1,8]$, activating family doctors - as a part of contracted prophylaxis procedures - to conduct trainings of self-examination and physical examination of mammary glands [9]. An important part of prophylaxis are tests for BRCA1 and BRCA2 genes mutation (paid examination, ca. 200-900PLN (polish currency) depending on the analysis range), USG examination with sonoelastography and nodules [10,11] (limited popularity, almost unavailable, paid - ca. 200PLN), USG with BACC test (paid, ca. 350PLN) and mammography.

Mammography is one of the cheapest diagnostic method. Its sensitivity is estimated at $80 \%$, and specificity up to $95 \%$. Due to those reasons it is included in screening program.

The purpose of screening tests is to diagnose the cancer at the non-clinical symptoms stage, when the prognosis are good and treatment less costly. Available statistics show that the total cost of breast cancer treatment in an early development stage is seven times lower than treatment of patients with related consequences of developed cancer with clinical symptoms (tumor) $[12,13]$.

Unfortunately due to the limited amount of money designated for prophylaxis, free mammography is provided only for women 50-69 years old [14]. Although the selection of this group seems logical (in Poland the peak of breast cancer cases is 50-69 years old (ca. 50\%) [1,15]), however this scheme ignores $50 \%$ of all cases [3]. Some of them face first symptoms before their 50s or after 69 years old, so later than defined by Polish health service and too late for free prevention program [16].

The important issue in Poland is low women's awareness resulting in low motivation for examination and appliance for examination.

The condition for successful screening examination is its mass scale and long-term agenda. It is established that only with $70 \%$ of participation level the mortality may be decreased by $25 \%$. In Poland it is still too low. However, there is a noticeable improvement in this matter. From the year 2006 to 2012 the number of mammography participants increased from $23 \%$ to $43 \%$ [17], in 2012 it was $46.96 \%$, and in $2013-47.18 \%$ [15].

Mammography examinations are proceeded as a part of Breast Cancer Early Detection Population Program. Priorities and methods are described in the Act from 1st July 2005 on setting a long-term program "National Program for Cancer Prevention". The aim of this program is to reduce illness and mortality caused by breast cancer and to increase the amount of breast cancer detections and the number of women participating in mammography. Among the actions included in the program aiming at increase of early detection is sending invitations and encouraging women to participate in screening examination. The Coordination Center and sixteen Local Coordination Centers are to proceed and evaluate progress. Their responsibility is to organize, supervise and control procedures described in the program.
Undoubtedly, almost 10 years of the Breast Cancer Early Detection Population Program has caused a noticeable improvement in an early breast cancer diagnosis. Much is still to be done, though.

Due to this reason, any initiatives, which are able to describe the current state, evaluate women's motivation, their knowledge and anxieties or difficulties in participation in screening tests, could cause upgrades in prophylaxis actions to achieve strategic aim (to diagnose cancer in the earliest development stage) as soon as possible.

\section{AIM}

The purpose of this work is to evaluate the basic knowledge about prophylaxis examination, women's participation level (including screening tests) and satisfaction with mammography examination among women in pre- and postmenopausal age in Lublin.

\section{MATERIAL AND METHODS}

There were 258 women participating in the survey. They were participants of mammography examination in the Witold Chodźko Institute of Rural Health in Lublin and in Specialist Clinic of the Stefan Cardinal Wyszynski Province Specialist Hospital in Lublin, at the turn of years 2011 and 2012.

The surveyed group consisted of 162 participants (73.3\%) at the age of 50-69 (qualified for free mammography program), 48 persons (18.6\%) 40-49 years old and 6 women $(2.3 \%)$ over 69 years old. Majority of them come from urban area -173 (67.1\%).

210 women $(81.4 \%)$ declared post primary education, 43 persons $(16.7 \%)$ technical education, 78 persons $(30.2 \%)$ declared secondary school education, 20 participants $(19.4 \%)$ post-secondary education and 69 women $(26.7 \%)$ declared higher education.

The majority of women were professionally active persons - $160(62 \%)$, out of which 104 participants were office workers $(40.3 \%)$. Almost half of surveyed group estimated their general health condition as good and very good (44.8\%).

A diagnostic survey was chosen as the methodology and the Own Questionnaire Survey was created and chosen as a tool for the following work. Participants filled the survey mostly in the waiting room or the corridor where patients wait for mammography.

\section{RESULTS}

Most of participants understand prophylaxis as preventing diseases, health care and free-of-charge examinations (Figure 1). This, unfortunately, seems to reflect the level of knowledge which can be summarized with the opinion that everyone but me is responsible for my prophylaxis, therefore examinations are free and often obligatory (state, health service, doctor). An opinion that prophylaxis should come as a result of aware lifestyle is not common $(22.1 \%$ of participants is convinced for expanding their knowledge about health threats).

The fact that just $14 \%$ of participants is convinced about the role that prophylaxis plays in early diagnosis and prevention of cancer is highly worrying. (Figure 1, multiple choice question). 


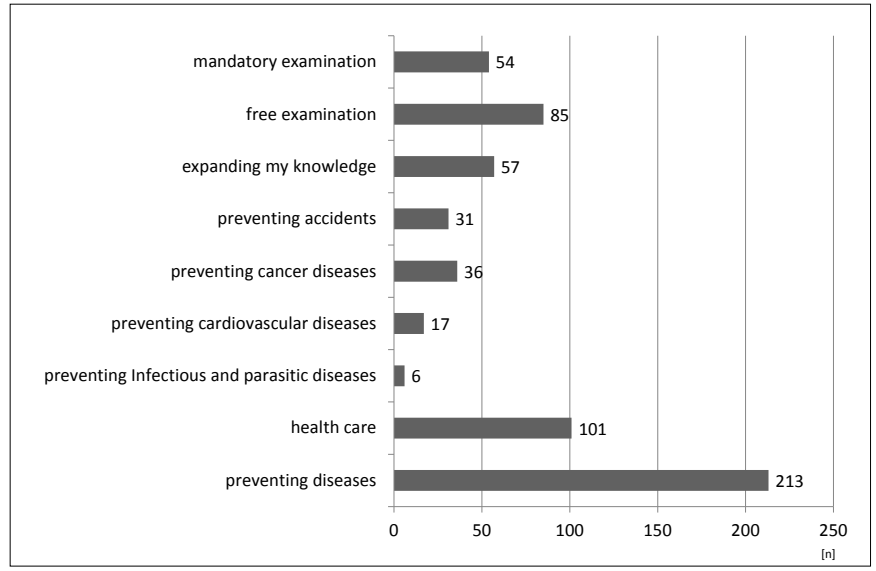

FIGURE 1. How do you understand the word "prophylaxis"?

The mammography examination was not their first preventing examination (Table 1) for most of surveyed people. Almost $20 \%$ of women have never participated (or could not remember participating) in any prevention examination. This fact is highly disturbing, bearing in mind that prophylaxis is written into public health care institutions including occupational medicine, family doctors and gynecologists.

Table 1. Have you ever taken part in prevention examination and have you been satisfied?

\begin{tabular}{|c|c|c|c|}
\hline \multirow{2}{*}{$\begin{array}{l}\text { Have you ever taken part } \\
\text { in prevention examination? [n(\%)] }\end{array}$} & \multirow{2}{*}{\multicolumn{2}{|c|}{$\begin{array}{c}\text { Yes } \\
211(81.8 \%)\end{array}$}} & No \\
\hline & & & $47(18.2 \%)$ \\
\hline \multirow{2}{*}{$\begin{array}{l}\text { Have you been satisfied } \\
\text { with the examination }[\mathrm{n}(\%)]\end{array}$} & Yes & No & \\
\hline & $186(88.2 \%)$ & $25(11.8 \%)$ & \\
\hline
\end{tabular}

The most commonly mentioned prevention examination were: cytology - 159 (61.6\%), mammography - $148(57.4 \%)$, blood pressure - (only) $140(54.3 \%)$, glycaemia - 114 (44.2\%), other blood tests - 106 (41.1\%).

This comes to a conclusion that prophylaxis conducted by health care facilities is on insufficient level.

Women who were not satisfied with prevention tests, most commonly said that their disappointment resulted from: too long waiting for examination and lack of precise information about the results (badly planned visit, too short time per patient or per examination); lack of empathy (from the health care worker) (Figure 2 - multiple choice question).

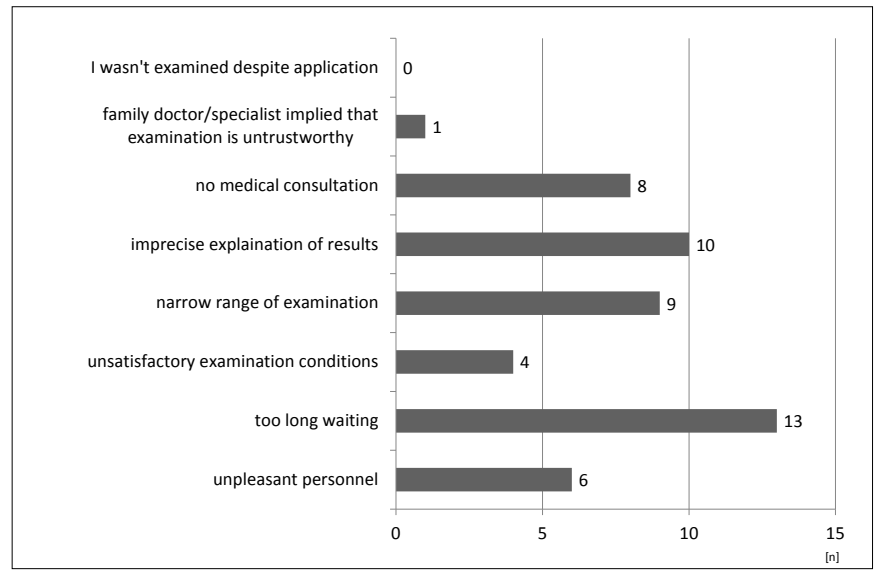

FIGURE 2. What were the reasons for your dissatisfaction with prophylaxis tests?
Only $71.7 \%$ respondents have, at least once, received invitation for mammography examination and $3 / 4$ of them accepted (Table 2).

Table 2. Have you ever received invitation for mammography, if so have you applied?

\begin{tabular}{|c|c|c|c|}
\hline \multirow{2}{*}{$\begin{array}{l}\text { Have you ever received } \\
\text { an invitation for mammography? }\end{array}$} & \multicolumn{2}{|c|}{ Yes } & No \\
\hline & \multicolumn{2}{|c|}{$211(71.7 \%)$} & $73(28.3 \%)$ \\
\hline \multirow{2}{*}{$\begin{array}{l}\text { Have you applied } \\
\text { for the examination? }\end{array}$} & Yes & No & \\
\hline & $139(75.1 \%)$ & $46(24.9 \%)$ & \\
\hline
\end{tabular}

The main reason for not applying for the examination was the fact that it was carried out by other doctor or the fear of the result (Figure 3 - multiple choice question).

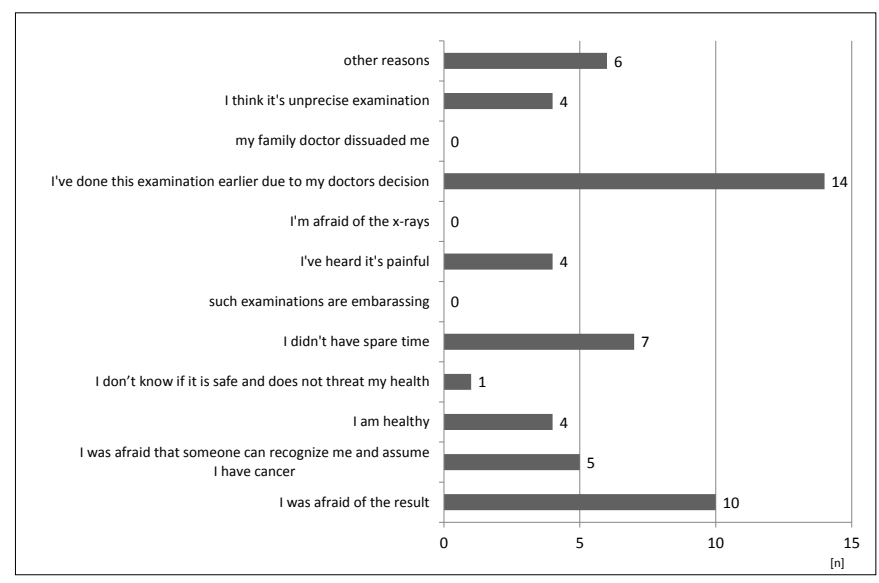

FIGURE 3. Why have not you accepted the invitation for free mammography test? (multiple choice question)

The majority of women $(95 \%)$ expressed their satisfaction with the examination.

Only 7 people (5\%) have remarks concerning organization: bad conditions in examination room, prolonging waiting time, discomfort during examination, no results description (Figure 4 - multiple choice question).

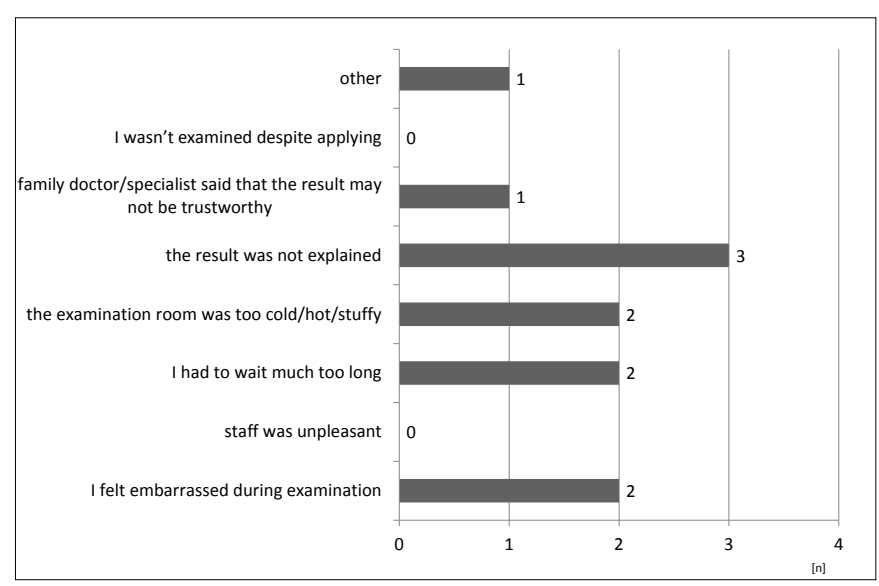

FIGURE 4. Why have not you been satisfied with the mammography examination?

Mammography examinations in Poland are made in facilities equipped with stationary mammography devices and in mobile mammography buses.

The name "mammobus" (the term means Mobile Mammography Coach, MMC or Mammography-In-Motion Mobile Unit) is commonly recognized according to the survey. $94.2 \%$ 
of respondents among mammography participants in stationary facilities was able to correctly describe term "mammobus".

Ca. $39 \%$ of respondents admitted that they have received an invitation for free examination in Mammography-In-Motion Mobile Unit ("mammobus") - Table 3.

Table 3. Have you ever received an invitation for examination conducted in so called "mammobus" and have you applied for it?

\begin{tabular}{|c|c|c|c|}
\hline \multirow{2}{*}{$\begin{array}{l}\text { Have you ever received an invita- } \\
\text { tion for examination conducted } \\
\text { in so called "mammobus"? }\end{array}$} & \multicolumn{2}{|c|}{ Yes } & No \\
\hline & \multicolumn{2}{|c|}{$94(38.7 \%)$} & $149(61.3 \%)$ \\
\hline \multirow{2}{*}{$\begin{array}{l}\text { Have you applied for } \\
\text { examination in „,mammobus”? }\end{array}$} & Yes & No & \\
\hline & $43(45.7 \%)$ & $51(54.3 \%)$ & \\
\hline
\end{tabular}

Almost 52\% of respondents (out of 243 persons who correctly identified term „mammobus”) said that they are interested in visiting „mammobus” in the future. $48 \%$ would prefer visiting facilities equipped with stationary mammography device. Women not willing to use ,mammobus” implied that such examination can be less precise and does not provide satisfactory intimacy, or that workers in mammobuses are less qualified than radiologists in hospitals or health care facilities (Figure 5 - multiple choice question).

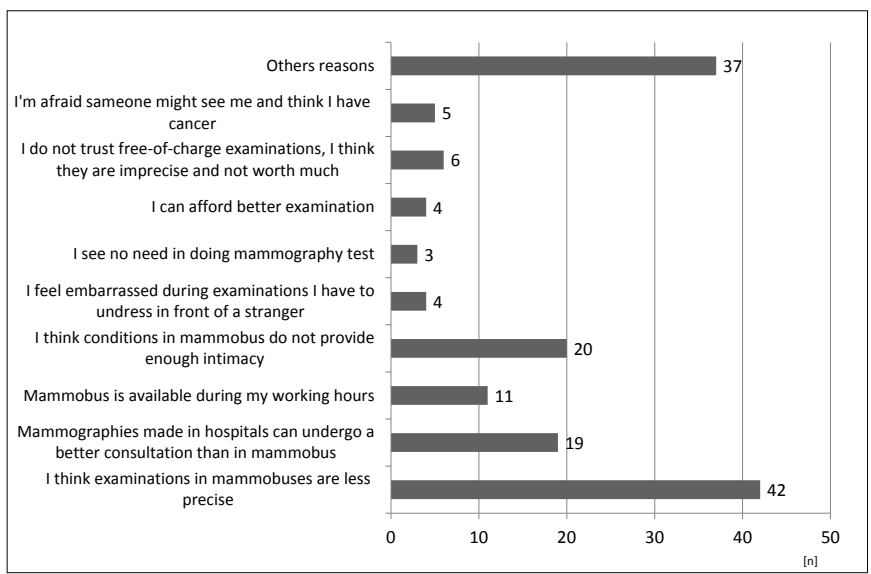

FIGURE 5. Why are not you interested in visiting mammobus?

\section{DISCUSSION}

According to Central Office for Coordinating Population Programs for Early Breast Cancer Detection and Prevention and Early Central Cervical Cancer Detection, mammography tests were conducted in $42.92 \%$ of women qualified for early breast cancer detection in Poland in 2012, and in 2013 in 43.3\% [19]. Numbers from one year to another do not show that any positive progress is being made. Such prophylaxis still covers women from 50 to 69 years old and significant majority of women are exposed to breast cancer (puberty, adulthood, post-menopausal). Data from different voivodships shows that in 2012 the biggest number of women participated in mammography examination in zachodniopomorskie voivodship $52.75 \%$ of all qualified women, in wielkopolskie voivodship $-50.6 \%$ and in lubelskie voi. $-50.20 \%$ (in 2013 the amount of applications decreased to $42.69 \%$ ). The smallest number of qualified to free mammography women took part in swietokrzyskie voi. $-33.39 \%$ and in podkarpackie voi. $-37.55 \%$ [19]. This leads to the conclusion that incomplete screening tests are caused by financial background (less satisfactory data comes from the poorest voivodships), but this not necessarily means that there are no other reasons bearing in mind that prevention agenda is not satisfactorily made - for instance cytology was conducted in $61.6 \%$ of respondents, blood pressure tests on $54.3 \%$, glycemia on $44.2 \%$, other blood tests (peripheral blood morphology, biochemical tests) in $41.1 \%$ of respondents.

Therefore, the main question is connected with the reason of such situation. The possibilities to be considered are as follows:

- caused by organizer (insufficient funds, poorly planned diagnostic facilities, insufficient publicity, badly conducted general health education);

- caused by executive (ignoring family doctors and gynecologists responsibilities, inefficient equipment or its lack, bad working hours, long queues, lack of empathy; embarrassing and unpleasant examination conditions);

- caused by participants themselves (ignoring the problem, no confidence in prophylaxis; embarrassment - physical and mental discomfort (laziness, threat of pain and devotion, not enough time, irrational scare of detecting disease (what if I make a test and it turns out I'm sick)).

Opinion that economy lays at the beginning of prophylaxis failure causes no doubt (more participants in more wealthy voivodships). Furthermore, the expenditures for prophylaxis are too low.

Statistical data from 2012 proves that Poland is second from the end when it comes to founds for prophylaxis and public health. The budget is 27USD per person (which is even less than the price for USG examination with Power Doppler, mammography examination or well proceeded cytology), in comparison to the Netherlands budget which reaches to 227 USD per person annually [20].

This causes difficulties in organizing efficient, commonly available medical facilities conducting prevention examination and results in searching for semi-solutions (mobile mammography units replaced by mammobuses, laboratory biochemical analysis are shifted into less precise methods of bloodglucose-meters, mobile cholesterol analysis devices, blood pressure measure devices without interchangeable sleeves incl. sleeves for children), limited (unsuitable) working hours, last but not least - limited amount of preventive examination. The range of prophylaxis examination differs among countries e.g. in France screening tests for cancer is partly paid (70\% refund), but provide early diagnosis not only for breast or cervical cancer but also prostate, large intestine and skin cancer (skin after preliminary dermatologist examination); in Sweden screening programs are free of charges and focused on early diagnosis of lung cancer among active and passive smokers, ovarian cancer (among people with family history of cancer or carriers of BRCA1 or BRCA2 gene) [21] or covering limited population with examination (in Poland free mammography is for women 50-69 years old, in Sweden 40-69 years old [22] in New Zealand 45-69 years old [23].

A lower efficiency of preventive actions in poorer regions may also be related to living, social or cultural conditions. The influence of tradition or historical background cannot be omitted when talking about taking care with one's health. People living in poverty and facing multiple problems put less effort in planning and implementing any health care programs, therefore they care less about the future and the quality of life. This is a undisputable fact [24-26].

Even today there are regions in Poland, where people boast about their health but their understanding of well-being is not 
reflected in doctor's diagnosis. Such people are using selftreatment and never undergo any prophylaxis programs.

A survey (ordered by MSD Foundation for Health of Women conducted by Millward Brown SMG/KRC from $23^{\text {rd }}-30^{\text {th }}$ April 2010 on 652 women - 25-50 years old), indicated that women over 55 years old (15\%) have never made a mammography test; $6 \%$ of women has never visited gynecologist (women with basic education from rural region, aged over 55) [27].

A survey program "Poles Health Awareness" by NationaleNederlandern made by the Millward Brown Insitute Inc with CATI technic in April 2015 on representative sample of Poles aged 20-55 [28] shows that failures in preventive activities are rooted in psyche, mentality and habits. Women in their 30s with higher education living in midsized cities participate in examinations most commonly. Men take care of their body with the symptoms of failure [28].

Lack of time $-33 \%$, not feeling it is necessary $-31 \%$, no evident symptoms $-20 \%$ and laziness $-3 \%$, are the most common reasons for ignoring prophylaxis indicated in Millward Brown Inc survey. Only $8 \%$ shows objective difficulties problems with arranging a visit at health facility [28].

Those subjective reasons are responsible for screening tests setbacks.

In our own survey $24.9 \%$ of women refused to participate in mammography examination. Those women were provided with the invitation, were scheduled but did not decide to participate (Table 2) - in such case it is not the organizer to be blamed but those subjective factors, depending on the patients.

It seems possible that decision on participating or not in the screening examinations depends on personal (or friends' and relatives') previous experiences of other preventive examinations.

The survey also shows that patients are unsatisfied due to reasons the organizer cannot avoid - long time of waiting for examination, unpleasant or embarrassing conditions, not fully explained results (Figure 4). On the other hand, it seems possible that negative attitude towards examinations can be created by rumors and gossips, for example a belief that mammobus' workers are less qualified than hospital staff, and the equipment is not that effective (Figure 5).

Personal experience and family or friends health problems can encourage to participate in tests. For instance the most encouraging factors indicated in Millward Brown Inc survey (from 2015) are: fear of disease $-29 \%$, a need for peace and confidence about health $-21 \%$, relative or friend disease or death $-10 \%$, long life will - 9\% [28].

Too low level of women' participation in screening tests is a fact. The most urgent need is to monitor and to find the reason for this situation. Knowledge that subjective factors are the ones responsible for that, gives a hope for relatively cheap and effective increase of participants (health education, increase in awareness by family doctors and gynecologists).

\section{CONCLUSIONS}

1. The number of participants in preventive examinations and in screening tests is unsatisfactory.

2. Numerous subjective factors cause this situation.

3. Many women still do not trust mammography tests made in mobile mammography facilities.

\section{REFERENCES}

1. Smaga A, Mikułowska M, Komorowska A, et al. Rak piersi w Polsce. leczenie to inwestycja. Warszawa: Roche Polska Sp. z o.o.;2014.

2. International Agency for Research on Cancer. World Health Organization; http://globocan.iarc.fr/Pages/fact_sheets_cancer.aspx [Available: 2015. 11.03]

3. Wojciechowska U, Didkowska J. Zachorowania i zgony na nowotwory złośliwe w Polsce. Krajowy Rejestr Nowotworów, Centrum Onkologii Instytut im. Marii Skłodowskiej-Curie. [http://onkologia.org.pl.] (Available: 2015.11.12)

4. Perkins EA, Small BJ, Balducci L, et al. Individual differences in well-being in older breast cancer survivors. Crit Rev Oncol/Hematol. 2007;62:7483.

5. Helgeson VS, Tomich PL. Surviving cancer: A comparison of 5-year disease-free breast cancer survivors with healthy women. Psycho-Oncology. 2005; $14: 307-17$.

6. Manne SL, Ostroff JS, Norton TR, et al. Cancer-specific self-efficacy and psychosocial and functional adaptation to early stage breast cancer. Ann Behav Med. 2006;331(Suppl. 2):145-54.

7. Oh S, Heflin L, Meyerowitz BE, et al. Quality of life of breast cancer survivors after a recurrence: A follow-up study. Breast Cancer Res Treat. 2004;87:45-57.

8. Polska Unia Onkologii. Badania profilaktyczne. [http://www.puo.pl/badania-profilaktyczne/rak-piersi] (Available: 2015.11.12)

9. Godycki-Ćwirko M, Tomiak E, Wrzeciono B, et al. Zakres profilaktyki w podstawowej opiece zdrowotnej. Probl Med Rodz. 2009:11(Suppl. 1):1522.

10. Gheonea IA, Donoiu L, Camen D, et al. Sonoelastography of breast lesions: a prospective study of 215 cases with histopathological correlation. Rom J Morphol Embryol. 2011;52(Suppl. 4):1209-14.

11. Leong LC, Sim LS, Lee YS, et al. A prospective study to compare the diagnostic performance of breast elastography versus conventional breast ultrasound. Clin Radiol. 2010;65(Suppl. 11):887-94.

12. Wronkowski Z, Chmielarczyk W. Znaczenie badań przesiewowych w zwalczaniu raka piersi. Sł Zdr. 2000;24-26:2917-9.

13. Zapała E, Brożek J, Jaeschke R. Mammografia w badaniu przesiewowym w kierunku raka piersi- przegląd systematyczny. Med Prakt. 2007;02:14850 .

14. NFZ. Programy profilaktyczne. Populacyjny Program Wczesnego Wykrywania Raka Piersi (mammografia). [http://www.nfz.gov.pl/dla-pacjenta/ programy-profilaktyczne/] (Available: 2015.11.12)

15. Minister Zdrowia. Sprawozdanie $\mathrm{z}$ realizacji Narodowego Programu Zwalczania Chorób Nowotworowych w 2013 r. Warszawa; 2014. [http:// www.mz.gov.pl/_data/assets/pdf_file/0004/18850/Sprawozdanie-NPZCHN-2013r.pdf] (Available: 2015.11.12)

16. Wywiad z lek. Med. Małgorzatą Stusińską z Zakładu Radiologii w Centrum Onkologii w Bydgoszczy - Diagnozowanie Raka Piersi; [http:// www.pfm.pl/baza_chorob/choroby-nowotworowe/diagnozowanie-rakapiersi-/873] (Available: 2015.11.03)

17. PAP/Rynek Zdrowia. Mammografia i cytologia: dwukrotna poprawa zgłaszalności w ciągu ostatnich 6 lat. Rynek Zdrowia. [http://www. rynekzdrowia.p1/Uslugi-medyczne/Mammografia-i-cytologia-dwukrotnapoprawa-zglaszalnosci-w-ciagu-ostatnich-6-lat,131562,8.html] (Available: 2015.11.12)

18. Śliwczyński A, Rzeźnicki A, Czeleko T, et al. Chorobowość oraz finansowanie terapii nowotworów w Polsce latach 2002-2011 wg danych Narodowego Funduszu Zdrowia. Nowotwory. J Oncol. 2014;64 (Suppl. 2):109-18

19. Kozierkiewicz A. Indeks Sprawności Ochrony Zdrowia 2015. Uczestnictwo w badaniach mammograficznych. Dane i analizy. Kraków; 2015.

20. Wojtyniak B, Goryński P, Moskalewicz B. Sytuacja zdrowotna ludności Polski i jej uwarunkowania. Warszawa: Narodowy Instytut Zdrowia Publicznego. Państwowy Zakład Higieny; 2012.

21. Cancer screening schemes in France.[http://www.connexionfrance.com/ cancer-screening-france-costs-jargon-explained-news-article.html] (Avaliable: 10.12.2025).

22. Taylor R, Wall M, Morrell S. Interval cancers in Breast Screen Aotearoa 1999-2007. Independent Monitoring Group. School of Public Health and Community Medicine. University of New South Wales for BreastScreen, Aotearoa; 2012.

23. Autier P, Koechlin A, Smans M, et al. Mammography screening and breast cancer mortality in Sweden. JNCI - JNATL.2012;18;104(Suppl. 14):1080-93.

24. Scarinci IC, Garcia FAR, Kobetz E, et al. Cervical Cancer Prevention: New Tools and Old Barriers. Cancer. 2010;11 (Suppl. 11):2531-42. 
25. Peres RS, dos Santos MA. Breast cancer, poverty and mental health: emotional response to the disease in women from popular classes. Revista Latino-Americana de Enfermagem. 2007,15. On-line version ISSN 15188345 .

26. Thomas SM, Fick AC. Women's health. Part II: individual, environmental and economic factors affecting adherence to recommended screening practices for breast cancer. J LSMS. 1995;147(Suppl. 4):149-55.

27. Instytut Praw Pacjenta i Edukacji Zdrowotnej. 6 proc. Polek nigdy nie było u ginekologa. [http://www.prawapacjenta.eu/?pId=2417] (Available 10.12.2015)

28. Nationale Nederlanden. Miej serce do zdrowia - raport o świadomości zdrowotnej Polaków 2015.
Corresponding author

Anna Jurek

Chair and Department of Public Health,

Medical University of Lublin

1 Chodźki St., 20-093 Lublin

E-mail: kizzp@wp.pl 